\title{
Perlindungan Hukum Terhadap Masyarakat yang Terpapar Limbah B3
}

\author{
Zainal Abidin'1, Zul Akli² ${ }^{2}$ Johari $^{3}$ \\ Dosen Fakultas Hukum Universitas Malikussaleh
}

\begin{abstract}
This research examines the legal protection of people who are victims of the B3 madical waste. This research is a qualitative research with literature study. The main sources in this research are written sources in the form of books, research results, and laws which related to the issue. The results showed that the law provides protection to people who are exposed to the B3 madical waste, both criminal and civil law. When a dispute happening between the community and the company, the solution can be done in two ways, litigation and non-litigation. Settlement of environmental disputes through channels outside the court according to Article 85 paragraph (3) can only be done by using the services of a mediator and / or arbitrator to help resolve the dispute. Active community participation can be carried out by referring to Article 86 of the PPLH Law by establishing a free and impartial environmental dispute resolution institution facilitated by the government and local governments.
\end{abstract}

Key Words: Legal Protection, Community, Hazardous Waste

\begin{abstract}
Abstrak
Penelitian ini mengkaji tentang perlindungan hukum kepada masyarakat yang menjadi korban dari limbah B3. Penelitian ini merupakan penelitian kualitatif dengan studi kepustakaan. Sumber utama dalam penelitian ini adalah sumber tertulis berupa buku-buku, hasil penelitian, dan perundang-undangan yang berhubungan dengan masalah tersebut. Hasil penelitian menunjukkan bahwa pada dasarnya hukum memberikan perlindungan kepada masyarakat yang terpapar limbah B3, baik secara pidana maupun perdata. Apabila terjadi sengketa antara masyarakat dengan perusahaan penyebab limbah maka penyelesaiaanya dapat dilakukan melalui dua cara yaitu secara litigasi dan non litigasi. Penyelesaian sengketa lingkungan hidup melalui jalur di luar pengadilan menurut Pasal 85 ayat (3) hanya dapat dilakukan dengan menggunakan jasa mediator dan/atau arbiter untuk membantu menyelesaikan sengketa. Partisipasi aktif masyarakat dapat dilakukan dengan merujuk Pasal 86 Undang-undang PPLH dengan membentuk lembaga penyelesaian sengketa lingkungan hidup yang bersifat bebas dan tidak memihak dengan difasilitasi oleh pemerintah dan pemerintah daerah.
\end{abstract}

Kata Kunci:

Perlindungan Hukum, Masyarakat, Limbah B3 


\section{A. PENDAHULUAN}

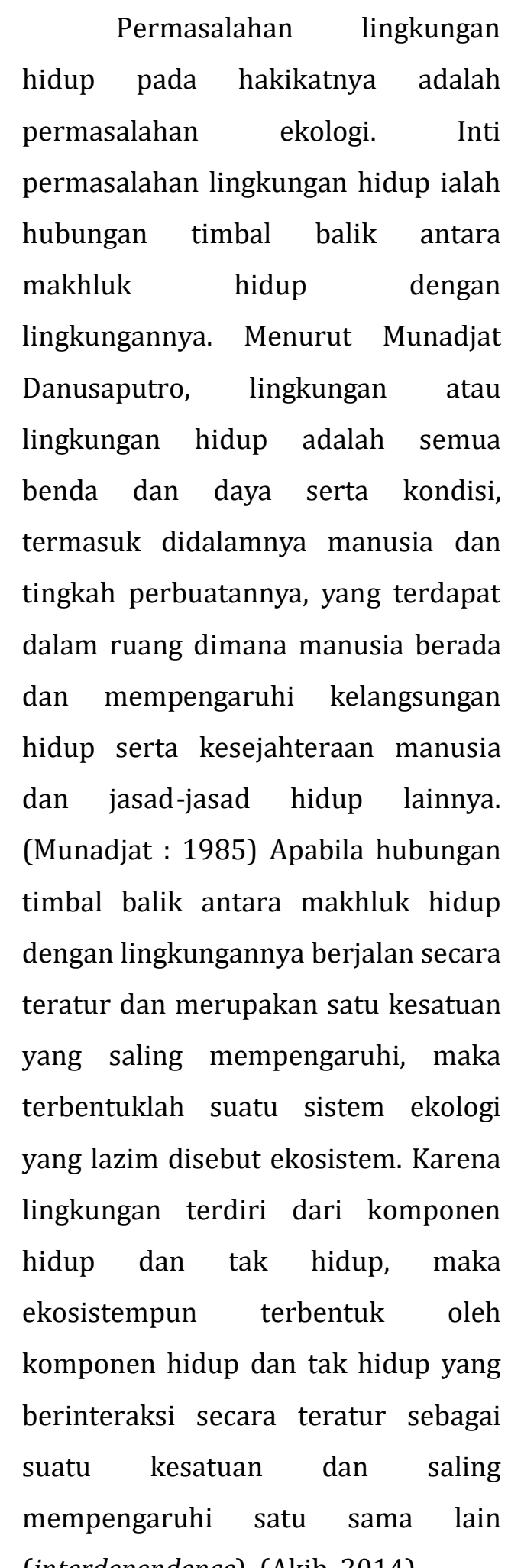

Bertalian dengan hal tersebut di atas, maka peningkatan pembangunan mengandung risiko pencemaran dan perusakan lingkungan yang berakibat pada rusaknya struktur dan fungsi dasar ekosistem yang menjadi penunjang kehidupan. Hal semacam itu merupakan beban sosial, karena pada akhirnya masyarakat dan pemerintahlah yang harus menanggung beban pemulihannya. Terpeliharanya ekosistem yang baik dan sehat merupakan tanggung jawab yang menuntut peranserta setiap anggota masyarakat untuk meningkatkan daya dukung lingkungan.

Oleh karena itu, pembangunan (khususnya di bidang lingkungan) yang bijaksana harus dilandasi adanya wawasan lingkungan sebagai sarana untuk mencapai kesinambungan dan menjadi jaminan bagi kesejahteraan generasi sekarang dan mendatang. Kekayaan sumber daya alam yang dimiliki oleh bangsa Indonesia merupakan suatu modal penting dalam proses penyelenggaraan pembangunan nasional. 


\begin{abstract}
Perkembangan teknologi khususnya dalam bidang industri berkembang sangat pesat. Setiap negara selalu mendambakan pembangunan industri yang tangguh karena alasan-alasan sebagai berikut : (1) industri dianggap lebih mampu membuka lapangan kerja; (2) memproduksi barang-barang yang semula diimpor; (3) mendorong perkembangan teknologi; (4) menumbuhkan berbagai kegiatan yang saling berkaitan dalam jaringan industri sehingga mampu berfungsi sebagai pendorong pembangunan; dan (5) pembangunan industri merupakan bagian dari ikhtiar menuju ke struktur ekonomi yang lebih baik lagi. (Emil, 1992)
\end{abstract}

Sebagai reaksi dari akibat pembangunan dan indutrialisasi telah menyebabkan berbagai kerusakan dan pencemaran lingkungan. (Deni, 2014) Pembangunan industri yang dilakukan oleh perusahaanperusahaan atau badan hukum di samping membawa pengaruh positif, juga dapat membawapengaruh negatif seperti pencemaran atau perusakan lingkungan hidup. Namun demikian, salah satu dampak dari pengembangan sektor industri adalah timbulnya limbah, termasuk limbah bahan berbahaya dan beracun, baik limbah padat, cair maupun gas.

Berdasarkan penelitian yang dilakukan dari sejumlah perusahaan PT. Bahroni, Desa Krueng Simpo, Kecamatan Juli (Bireun), PT. Blang Ketumba, Desa Blang Gunci, Kecamatan Paya Bakong ( Aceh Utara), PT. Aceh Loka Makmur Sentosa, Desa Seuneubok Lapang, Kecamatan Peureulak Timur (Aceh Timur), PT. Perta Arun Gas dan sebagai contoh perusahaan PT. Pupuk Iskandar Muda (PT.PIM Lhokseumawe). namun dalam pelaksanaannya terdapat ketidak sesuaian karena tempat pengolahan limbah cair (bak penampung limbah cair/IPAL) ukurannya pas-pasan sehingga pada saat hujan turun deras bak penampungan air limbah tidak mampu menampung limbah cair yang sudah tercampur dengan air hujan sehingga meluap dan airnya langsung masuk kelaut tampa melalui proses pengolahan terlebih dahulu, hal ini sangat di sayangkan terhadap kehidupan biota laut juga berdampak pada nelayan. Lain halnya dilokasi lain yakni tempat pengumpulan limbah cair yang terdapat di Claster I milik Exxon Mobil Oil yang sudah tidak terpakai lagi. 
PT Exxon Mobil membuang limbah mercury $(\mathrm{Hg})$ atau logam raksa ke sawah dan sungai di Cluster I Syamtalira Aron, di Desa Hueng, Kecamatan Tanah Luas, Aceh Utara. Akibatnya areal sawah warga rusak dan sungai tercemar. Bagi warga yang menggunakan air sungai untuk mandi dan mencuci atau sebagianya, mengalami gatal-gatal, bahkan didapati banyak ikan yang mati karena limbah mercury milik PT Exxon Mobil. Merkuri merupakan produk samping yang dihasilkan dalam proses pemurnian gas alam dan tentu saja jumlahnya sudah puluhan ton sejak proses pengolahan gas berlangsung. rentang waktu mulai tahun 1977 sampai sekarang perusahaan itu telah memproduksi bahan B3 alias zat kimia berbahaya termasuk mercury dalam jumlah besar. Namun sampai saat ini, perusahaan Amerika itu masih merahasiakan keberadaan limbah kimia yang diproduksinya, apakah ditanam dalam tanah atau dibuang ke daerah lain. Sesuai dengan Permen LH No 18/2009 tentang Tata Cara Perizinan Pengelolaan Limbah B3 pasal 2 ayat (2) disebutkan, penghasil limbah B3 tidak dapat melakukan kegiatan penggumpalan limbah B3 sebagaimana dimaksudkan pada ayat (1) huruf c. Dengan demikian, pihak Exxon Mobile sebagai penghasil limbah tidak diperkenankan mengelola limbah merkurinya sendiri, tetapi harus menyerahkannya kepada pihak lain.

Limbah cair dibiarkan begitu saja tampa ada pengawasan ataupun usaha pengolahan hanya dibiarkan begitu saja sehingga dampat yang ditimbulkan sangat riskan sekali terhadap kelangsungan hidup makhuk hidup. Seyogyanya penimbunan limbah B3 harus mengutamakan perlindungan terhadap kehidupan dan kesehatan manusia serta perlindungan terhadap lingkungan.

Dari uraian tersebut diatas adapun yang menjadi permasalahan adalah Bagaimanakah Perlindungan Hukum Terhadap Masyarakat Akibat Kelalaian Yang Dilakukan Oleh Perusahaan Penerima Kerja Pengelolaan Limbah B3dalam Hal Terjadinya Pencemaran Lingkungan. Penelitian ini adalah penelitian hukum normatif yang akan melihat dasar hukum dari permasalahan tersebut dan juga kesesuaian aturan hukum dengan asas hukum. 
Pengumpulan data dalam penelitian ini menggunakan studi pustaka sebagai primer.

\section{B. PEMBAHASAN}

1. Perlindungan Hukum Terhadap Masyarakat Akibat Kelalaian Yang Dilakukan Oleh Perusahaan Penerima Kerja Pengelolaan Limbah B3dalam Hal Terjadinya Pencemaran Lingkungan

Perumusan Draf Akademik Rancangan Undang-Undang (Draf Akademik RUU) Pengelolaan Sumber Daya Genetika 2012 telah dijalankan pada tahun 2000 yang dinamai dengan Draf Akademik Rancangan Undang Undang Pelestarian dan Pemanfaatan Sumber Daya Genetika. Draf tersebut diketuai oleh Kementerian Pertanian dan telah menghasilkan Draf Akademik RUU Pelestarian dan Pemanfaatan Sumber Daya Genetika 2003 dan RUU Pelestarian dan Pemanfaatan Sumber Daya Genetika 2003. Namun semasa itu, Draf Akademik RUU Pelestarian dan Pemanfaatan Sumber Daya Genetika 2003 belum dimasukkan dalam Program Legislasi Nasional.

Sesuai dengan Pasal 1 ayat 23 UU Nomor 32 Tahun 2009 tentang Perlindungan Dan Pengelolaan Lingkungan Hidup (UUPPLH) yang memberikan penjelasan tentang pengelolaan limbah B3. Penjelasan tersebut menjadikan dasar terhadap kegiatan-kegiatan dalam melakukan pengelolaan oli bekas yang meliputi hal-hal yang mencakup penyimpanan, pengumpulan, pengangkutan, pemanfaatan, pengolahan, dan penimbunan.

\section{Memperhatikan ketentuan-} ketentuan mengenai pengelolaan limbah B3 tersebut, maka dapat di sebutkan bahwa pengaturan terhadap pengelolaan limbah B3 dapat didasarkan juga di dalam UndangUndang Nomor 32 Tahun 2009 tentang Perlindungan Dan Pengelolaan Lingkungan Hidup yaitu sebagai berikut:

1. Melakukan perbuatan pengelolaan limbah B3 jenis oli bekas tanpa izin dan sanksi pidana yang diberikan ialah dipidana penjara dengan pidana penjara minimal 1 tahun dan maksimal 3 tahun serta denda paling sedikit 1 miliar rupiah dan paling banyak 3 miliar rupiah (Pasal 102 UUPPLH);

\section{Melakukan perbuatan} menghasilkan limbah B3 jenis oli bekas dan tidak melakukan pengelolaannya dan sanksi pidana yang diberikan ialah dipidana penjara 
dengan pidana penjara minimal 1 tahun dan maksimal 3 tahun serta denda paling sedikit 1 miliar rupiah dan paling banyak 3 miliar rupiah (Pasal 103 UUPPLH);

3. Melakukan perbuatan dumping limbah B3 jenis oli bekas dan/atau bahan ke media lingkungan hidup tanpa izin dan sanksi pidana yang diberikan ialah dipidana penjara paling lama 3 tahun serta denda paling banyak 3 miliar rupiah (Pasal 104 UUPPLH);

4. Melakukan perbuatan memasukkan limbah B3 jenis oli bekas ke dalam wilayah Negara Kesatuan Republik Indonesia dan sanksi pidana yang diberikan ialah dipidana penjara paling singkat 5 tahun dan paling lama 15 tahun serta denda paling sedikit 5 miliar rupiah dan paling banyak 15 miliar rupiah (Pasal 106 UUPPLH);

5. Melakukan perbuatan memasukkan B3 jenis oli bekas yang dilarang menurut peraturan perundang-undangan ke dalam wilayah Negara Kesatuan Republik Indonesia dan sanksi pidana yang diberikan ialah pidana penjara paling singkat 5 tahun dan paling lama 15 tahun serta denda paling sedikit 5 miliar rupiah dan paling banyak 15 miliar rupiah (Pasal 107 UUPPLH). 2. Sistem Pertanggungjawaban Pidana Korporasi Dalam Tindak Pidana Pengelolaan Limbah Bahan Berbahaya dan Beracun (Oli Bekas) UndangUndang Nomor 32 Tahun 2009 Tentang Perlindungan dan Pengelolaan Lingkungan Hidup (UUPPLH) dijadikan sebagai payung hukum (umbrella act) dari undangundang lain (sektoral) di bidang pelestarian lingkungan hidup, rumusan yang umum dan abstrak tersebut diharapkan dapat menjangkau perbuatan pencemaran dan/atau perusakan lingkungan yang diatur atau yang akan diatur dalam undang-undang sektoral lainnya.

Dalam UUPPLH, mengenai ketentuan pertanggungjawaban pidana yang berkaitan dengan badan usaha yang berbadan hukum dan tidak berbadan hukum diatur dalam Pasal 116 sampai dengan Pasal 120. Mengenai pertanggungjawaban pidana korporasi terhadap tindak pidana pengelolaan limbah B3 jenis oli bekas dapat di terapkan beberapa prinsip atau teori. Seperti berdasarkan prinsip "vicarious liability" dalam sistem hukum Anglo Saxon, suatu pertanggungjawaban 
pidana yang dibebankan kepada seseorang atas perbuatan orang lain (the legal responsibility of one person for the wrongful acts of another).

Maksudnya ialah pimpinan korporasi atau siapa saja memberi tugas atau perintah bertanggungjawab atas perbuatan yang dilakukan oleh bawahan atau karyawannya. Tanggungjawab ini diperluas hingga mencakup perbuatan- perbuatan yang dilakukan oleh orang-orang berdasarkan hubungan kerja maupun hubungan lain. Dengan demikian siapa saja yang bekerja dan dalam hubungan apa saja pekerja itu dilakukan, selama hal tersebut dilakukan dalam hubungannya dengan korporasi, menjadi tanggungjawab korporasi. (Alvi, 2011)

Selain prinsip "vicarious liability" dalam pertanggungjawaban pidana terhadap korporasi juga dikenal dengan Teori Identifikasi atau Doktrin Direct Liability. Doktrin direct liability merupakan dasar pertanggungjawaban korporasi terhadap tindak pidana. Oleh karena itu korporasi bertanggung jawab atas tindak pidana yang dilakukan oleh pejabat senior di dalam korporasi, sepanjang ia melakukannya dalam ruang lingkup kewenangan atau dalam urusan transaksi korporasi.

Doktrin identifikasi atau direct liability doctrine ini di samping dapat digunakan untuk mempertanggungjawabkan korporasi di bidang hukum pidana, pada sisi lain juga dapat membatasi pertanggungjawaban korporasi. Apabila kejahatan dilakukan oleh karyawan atau agen yang tidak mempunyai status sebagai pejabat senior, korporasi tidak dapat dipertanggungjawabkan, kecuali undang-undang menetapkan dasar pertanggungjawaban yang lain. Doktrin direct liability, secara khusus dikembangkan demi menerapkan tanggung jawab korporasi, dan pada dasarnya bertujuan untuk meniru pembebanan tanggung jawab terhadap manusia. Doktrin direct liability ini bergantung pada personifikasi badan hukum.

Doktrin ini mengidentifikasi pola tindakan dan pikiran dari individu tertentu dalam korporasi yang disebut dengan istilah organ korporasi - yang bertindak dalam ruang lingkup kewenangan mereka dan atas nama badan korporasi, 
sebagai tindakan dari korporasi itu sendiri. Di dalam pokok pemikiran tentang pertanggungjawaban pidana juga terdapat konsep kesalahan Gen Starf Zonder Schuld (Tiada Pidana Tanpa Kesalahan) sebagai dasar untuk meminta pertanggungjawaban terhadap seseorang dan sesuatu badan hukum yang dikenal di Indonesia. (Erdianto, 2010) Kesalahan itu mengandung unsur pencelaan terhadap si pelaku karena telah melakukan tindak pidana (yang telah dirumuskan di dalam peraturan perundang-undangan) dan mengandung unsur pertanggungan jawab dalam hukum pidana. (Hamdan, 2000) Mengenai kesalahan terhadap suatu badan hukum dalam hal pengelolaan lingkungan hidup dilihat dari konsep pertanggungjawaban pidana terhadap korporasi tersebut itu sendiri.

$$
\text { Mengenai }
$$

pertanggungjawaban penerapan berdasarkan kesalahan (liability based on fault) dalam UUPPLH dapat dilihat dalam beberapa pasal, seperti Pasal 101 UUPPLH tentang perbuatan melepaskan atau mengedarkan produk rekayasa genetik ke media lingkungan, dan yang berhubungan dengan pengelolaan limbah B3 dalam
Pasal 102 UUPPLH mengenai pengelolaan limbah B3 tanpa izin, dan Pasal 103 UUPPLH tentang menghasilkan limbah B3 dan tidak melakukan pengelolaan, Pasal 106 UUPPLH mengenai memasukkan limbah B3 ke wilayah Indonesia.

Berdasarkan pasal tersebut dapat dilihat bahwa kesalahan dalam melakukan pengelolaan lingkungan hidup khususnya pengelolaan limbah B3, yang menyebabkan rusak atau tercemarnya lingkungan hidup. Dari penerapan pertanggungjawaban pidana dalam UUPPLH dapat dijelaskan bahwa konsep kesalahan mempunyai hubungan erat dengan pengelolaan lingkungan hidup termasuk juga pengelolaan limbah B3. Oleh karena itu, Korporasi sebagai subjek hukum pidana dalam UUPPLH dapat dipersalahkan dan dimintai pertanggungjawaban pidananya atas kesalahan dalam melakukan tindak pidana pengelolaan limbah B3.

Ketentuan pidana terhadap direksi diatur dalam Pasal 155 Undang-Undang Nomor 40 Tahun 2007 tentang Perseroan Terbatas (UUPT). Pasal tersebut menjelaskan bahwa tanggung jawab direksi atas kesalahan dan kelalaiannya yang 
diatur dalam undang-undang ini tidak mengurangi ketentuan yang diatur dalam KUHPidana maupun di luar KUHPidana. Perseroan yang menjalankan usahanya di bidang lingkungan hidup yang berkaitan dengan pengelolaan limbah B3 setiap kegiatannya harus sesuai dengan UUPPLH. kewajiban setiap penanggungjawab usaha (Direksi) untuk melakukan pengelolaan limbah hasil usaha dan/atau kegiatannya, termasuk pengelolaan limbah B3 jenis oli bekas.

Direksi dalam hal mengurus perseroan mempunyai tanggungjawab yang besar terhadap pengelolaan limbah B3 jenis oli bekas tersebut, oleh karena itu setiap tindak pidana pengelolaan limbah B3 dapat dimintai pertanggungjawaban terhadap direksi sesuai dengan ketentuan hukum lingkungan yang berlaku. Dengan demikian, direktur tidak dapat melepaskan diri dari pertanggungjawaban pidana dalam hal terjadinya pencemaran dan/atau kerusakan lingkungan dari akibat pengelolaan limbah B3 hal ini disebabkan karena direksi memiliki "kemampuan" dan "kewajiban" untuk mengawasi kegiatan korporasi termasuk kewajiban untuk melakukan pelestarian lingkungan hidup.

\section{Penyelesaian Sengketa Secara Perdata terhadap Pelanggaran Tanggung Jawab Mutlak (Strict Liability) dalam Pengelolaan Limbah Bahan Berbahaya dan Beracun}

Pelanggaran tanggung jawab mutlak (strict liability) dalam pengelolaan limbah bahan berbahaya dan beracun sangat merugikan semua kalangan, baik masyarakat maupun pemerintah. Kehidupan dan kesehatan masyarakat akan sangat terganggu dengan pencemaran yang terjadi. Program-program pembangunan oleh pemerintah akan terkendala pula dengan adanya pencemaran limbah B3. Menilik embrio persoalan demikian, Undangundang PPLH mengakomodasi penyelesaian sengketa dengan memberikan hak gugat kepada pemerintah, pemerintah daerah, masyarakat dan organisasi lingkungan hidup.

Hak gugat pemerintah dan pemerintah daerah diatur pada Pasal 90, instansi pemerintah dan pemerintah daerah yang bertanggung jawab di bidang lingkungan hidup berwenang mengajukan gugatan ganti rugi dan tindakan tertentu terhadap 
usaha dan/atau kegiatan yang menyebabkan pencemaran dan/atau kerusakan lingkungan hidup yang mengakibatkan kerugian lingkungan hidup. Hak gugat masyarakat diatur pada Pasal 91 dimana masyarakat berhak mengajukan gugatan perakilan kelompok untuk kepentingan dirinya sendiri dan/atau untuk kepentingan masyarakat apabila mengalami kerugian akibat pencemaran dan/atau kerusakan lingkungan hidup.

Gugatan dapat diajukan apabila terdapat kesamaan fakta atau peristiwa, dasar hukum, serta jenis tuntutan di antara wakil kelompok dan anggota kelompoknya. Hak gugat organisasi lingkungan hidup diatur pada Pasal 92, hak gugat tersebut guna kepentingan pelestarian fungsi lingkungan hidup. Hak mengajukan gugatan terbatas pada tuntutan untuk melakukan tindakan tertentu tanpa adanya tuntutan ganti rugi, kecuali biaya atau pengeluaran riil. Organisasi lingkungan hidup dapat mengajukan gugatan apabila memenuhi persyaratan diantaranya : berbentuk badan hukum, menegaskan di dalam anggaran dasarnya bahwa organisasi tersebut didirikan untuk kepentingan pelestarian fungsi lingkungan hidup; dan telah melaksanakan kegiatan nyata sesuai dengan anggaran dasarnya paling singkat 2 (dua) tahun. Sebagai langkah tindak lanjut terhadap hak gugat yang diberikan kepada pemerintah, pemerintah daerah, masyarakat dan organisasi lingkungan hidup, maka penyelesaian sengketa lingkungan hidup dapat dilaksanakan melalui pengadilan dan di luar pengadilan. Pada Pasal 84 Undang-undang PPLH menyebutkan pada pokoknya:

1. Penyelesaian sengketa lingkungan hidup dapat ditempuh melalui pengadilan atau di luar pengadilan.

2. Pilihan pengelesaian sengketa lingkungan hidup dilakukan secara suka rela oleh para pihak yang bersengketa.

3. Gugatan melalui pengadilan hanya dapat ditempuh apabila upaya penyelesaian segketa di luar pengadilan yang dipilih dinyatakan tidak berhasil oleh salah satu atau para pihak yang bersengketa.

Ganti kerugian dan pemulihan lingkungan diatur dalam Pasal 87 dengan ketentuan sebagai berikut :

1. Setiap penanggung jawab usaha dan/atau kegiatan yang melakukan perbuatan melanggar hukum berupa pencemaran dan/atau perusakan lingkungan hidup yang 
menimbulkan kerugian pada orang lain atau lingkungan hidup wajib membayar ganti rugi dan/atau melakukan tindakan tertentu.

2. Setiap orang yang melakukan pemindah tanganan, pengubahan sifat dan bentuk usaha, dan/atau kegiatan dari suatu badan usaha yang melanggar hukum tidak melepaskan tanggung jawab hukum dan/atau kewajiban badan usaha tersebut.

3. Pengasilan dapat menetapkan pembayaran uang paksa terhadap setiap hari keterlambatan atas pelaksanaan putusan pengadilan.

4. Besarnya uang paksa diputuskan berdasarkan peraturan perundang-undangan.

Penyelesaian sengketa lingkungan hidup melalui jalur di luar pengadilan menurut Pasal 85 ayat (3) hanya dapat dilakukan dengan menggunakan jasa mediator dan/atau arbiter untuk membantu menyelesaikan sengketa. Partisipasi aktif masyarakat dapat dilakukan dengan merujuk Pasal 86 Undangundang PPLH dengan membentuk lembaga penyelesaian sengketa lingkungan hidup yang bersifat bebas dan tidak memihak dengan difasilitasi oleh pemerintah dan pemerintah daerah.

Supaya sengketa lingkungan hidup dapat diselesaikan dengan baik dan pelaku usaha juga mau melaksanakan tanggung jawab mutlak sebagaimana diatur dalam Pasal 88 Undang-Undang PPLH, maka pemerintah pusat, pemerintah daerah, organisasi masyarakat dan seluruh lapisan masyarakat harus bersinergi melakukan pengawasan terhadap pelaksanaan tanggung jawab terhadap lingkungan oleh pelaku usaha. Sinergi dan kepedulian terhadap pelaksanaan tanggung jawab lingkungan dan kerjasama yang baik dengan pelaku usaha untuk mengingatkan peningkatan kepedulian terhadap lingkungan hidup akan meminimalkan terjadinya pencemaran limbah B3 pada lingkungan.

\section{KESIMPULAN}

Pada dasarnya hukum memberikan perlindungan kepada masyarakat yang terpapar limbah B3, baik secara pidana maupun perdata. Apabila terjadi sengketa antara masyarakat dengan perusahaan penyebab limbah maka penyelesaiaanya dapat dilakukan melalui dua cara yaitu secara litigasi 
dan non litigasi. Penyelesaian sengketa lingkungan hidup melalui jalur di luar pengadilan menurut Pasal 85 ayat (3) hanya dapat dilakukan dengan menggunakan jasa mediator dan/atau arbiter untuk membantu menyelesaikan sengketa. Partisipasi aktif masyarakat dapat dilakukan dengan merujuk Pasal 86 Undangundang PPLH dengan membentuk lembaga penyelesaian sengketa lingkungan hidup yang bersifat bebas dan tidak memihak dengan difasilitasi oleh pemerintah dan pemerintah daerah.

\section{DAFTAR PUSTAKA}

Oguamanam, 2011. 'Genetic resources \& access and benefit sharing: politics, prospects and opportunities for canada after nagoya', 22(2), Journal of Environmental Law and Practice, 87-201.

Danusaputro, M. 1986. Hukum Lingkungan, Buku I Umum, Binacipta, Jakarta.

Akib, M. 2014. Hukum Lingkungan Perspektif Global dan Nasional, Raja Grafindo Persada, Jakarta.

Bram, D. 2014, Hukum Lingkungan Hidup: Homo Ethic Menuju Eco Ethic, Gramata Publishing, Bekasi.

Syahrin, A. 2011. Ketentuan Pidana Dalam UU No.32 Tahun 2009 Tentang Perlindungan Dan Pengelolaan Lingkungan Hidup, Sofmedia. Jakarta.
Danusaputro, M. 1985. Hukum Lingkungan, Buku I Umum, Binacipta, Jakarta.

Salim, E. 1992. Lingkungan Hidup Dan Pembangunan, Mutiara Sumber Widya, Jakarta.

Dirdjosisworo, S. 1983. Pengamanan Hukum Terhadap Pencemaran Lingkungan Akibat Industri, Alumni, Bandung.

Erdianto, 2010/ Pokok-Pokok Hukum Pidana,:Alaf Riau, Pekan Baru.

Hamdan, M. 2000. Tindak Pidana Pencemaran Lingkungan Hidup, Mandar Maju Bandung. 